УДК $821.161 .2-2-3$

Сергій ЦІКАВИЙ

к. філол. наук, Донецький національний університет імені Василя Стуса

\title{
АНТИУТОПІЯ ТА ГЕТЕРОТОПІЯ: ФІКЦІЙНЕ МІСТО-ТЮРМА В ПОВІСТІ «МІСТО, В ЯКОМУ НЕ ХОДЯТЬ ГРОШІ» КУЗЬМИ СКРЯБІНА
}

Статтю присвячено аналізу художнього простору Чорнобильської зони в малодослідженій повісті А. Кузьменка. Стисло окреслено основні концепції просторовості в контексті геопоетичного дискурсу сучасної гуманітаристики. Спостережено ознаки руйнування референтного зв'язку простору Зони 3 реальним. Визначено, що сконструйований наративний простір може бути окреслений як гетеротопічний. Пострадянська антиутопічна складова твору в повісті ефективно деконструйована.

Ключові слова: місто, простір, локус, топос, паноптикон, антиутопія.

Повість Кузьми Скрябіна (А. Кузьменка) «Місто, в якому не ходять гроші» $€$ одним із, здається, найбільш показових взірців ситуації «постчорнобильскої бібліотеки» (Т. Гундорова). Уже перше наближення уможливлює включення цього твору до корпусу, установку якого дослідниця визначає як «недовіра до основних модернізаційних ідеалів просвіти, науки, раціональности, технології, фалогоцентризму, імпералізму, европеїзму» $[1,23]$. Одразу по виході одна з двох дебютних прозових речей фронтмена гурту «Скрябін» була визначена критиками як «похмура й абсолютно безвихідна антиутопія, дія якої відбувається на території Чорнобильської зони» (рос. «хмурая и абсолютно безысходная антиутопия, действие которой происходит на территории Чернобыльской зоны») [2]; «психологічний трилер ..., чергова антиутопія у постчорнобильському стилі “антигламур”» [3]; "short story y стилі "Очамимрі" та “Рівне/Ровно" Ірвания - фантастика постіндустріального періоду» [4]. Антиутопічне та альтернативно-історичне припущення, таким чином, були констатовані від самого початку вже оглядачами. Що ж до наукової літературознавчої рецепції твору поза 
літературно-критичними оцінками та оглядами, то вона вичерпується статтею Г. Саган [5], присвяченою індивідуально-авторському стилю. Враховуючи це, дослідження повісті «Місто, в якому не ходять гроші» Кузьми Скрябіна слід вважати актуальним.

Згадуючи історію написання повісті, автор апелює до досвіду сновидіння: «Ії сюжет мені наснився. Якось я відпочивав у Сгипті. Напився там жахливого місцевого рому, після якого мені привидівся жсахливий сон про місто, у якому немає грошей. Там за все доводиться розплачуватися послугами. За ночівлю у готелі - мити волоссям підлогу в туалеті, а за проїзд у таксі - їсти декілька ложок хрону. Сон був, як кіно. Наприкінці навіть титри показували. Вранц̧і прокинувся $i$ занотував те сновидіння» [Цит. за: 6]. Прикметно, що автор звертається до одразу двох виявів фіктивної реальності: сновидіння та кіно.

Ситуація сну, кошмару неодноразово реактуалізована в сюжеті повісті: героїня отримує в загадковий спосіб залізничний квиток, поки спить; проспавши дорогу, Аліса втрачає можливість вийти до прибуття на станцію, як планувала від початку; надалі думки про поганий сон дівчину вже не полишають: «Як би вона хотіла заплющчити очі $i$ розплющчити $\ddot{x}$ у себе в теплому ліжечку, біля якого тумбочка і иклянка теплого видохлого винця!» [7, 91]; «- Де я? Чи ичей кошмар - таки правда?» [7, 92]; “"Чом я не пташка, чом не літаю?" - згадала школу Аліса, і в уяві блиснув сон з дитячих років, у якому вона літала із синичками над своєю вулицеюю, спостерігаючи знайомі місия зверху» [7, 110]; «Алісі хотілося, щуоб цее був сон і нічого такого вона не чула» [7, 116]. Мотив сну поступово (від моменту потрапляння героїні в експериментальне місто) починає переплітатися 3 мотивом фільму. Аліса асоціює себе з персонажем фантастичної стрічки, переживає абсурдне відчуття власної включеності у вигаданий сюжет. Загострення ситуації абсурдності навколишньої дійсності сприяє переродженню героїні, іï свідомому бажанню зіграти в жорстокій грі в ролі вбивці та рятівниці випадкового знайомого. Вона чинить алогічно, виходячи 3 законів кінематографічних (приміром, попри 
ISSN 2308-1902 Актуальні проблеми української літератури і фольклору. 2017. № 25.

логіку раціо заходить у квартиру до незнайомців), а надалі свідомо чинить убивство за вбивством. У повісті докладно інтеріоризовано ситуацію переродження героїні $з$ ролі жертви на роль такої собі «героїні», яка легко натискає гачок. «Кімната являла собою квадратну коробку з нераціонально розставленими старими бомбетлями по периметру, їх було n'ять, з чого Аліса зробила висновок, щуо рівно стільки ж жило тут людей до Аварії. На стінах висіли фотки, як їх люблять вішати в селах - на одному аркуші під склом було наліплено до десяти різних епізодичних чорно-білих кавалків людської бідності $i$ розпачу. Збіловані обличчя з чорними від роботи руками $і$ з такими жс тяжкими посмішками, які аж ніяк не випромінювали радості. То були фотки людей, які вибиралися до міста пофоткатися три рази в житті - на паспорт, на весілля і на похорон. По спині дівчини пробіг мільйон мурашок в кирзових чоботах з підошвами, з яких стриміли цуяях й боляче впивалися в шкіру. Це й повернуло ї̈ до свідомості» [7, 130]. Інтер’єр, пов'язаний із травматичною пам’яттю, iз німотою спогаду про до-катастрофічне, до-чорнобильське життя, стає локусом перетворення Аліси 3 героя пасивного на героя активного. Конотований простір репрезентує злам глибоко традиційної реальності, iз іï простотою та невибагливістю (тріада позначених фото стадій: дорослішання, створення власної родини та смерть) під впливом нездоланної сили «Аварії». Локалізованість цієї лімінальної ситуації, просторова конкретизація переходу «жертва - хижак» вкупі зі своєрідною віднесеністю подій до деформованого топосу Чорнобиля, розбудови фіктивної версії Прип’яті вимагає уважного прочитання геопоетики твору, а відтак, просторові параметри повісті «Місто, в якому не ходять гроші» Кузьми Скрябіна (А. Кузьменка) становлять мету пропонованого дослідження.

О. Стусенко вважає, що в тому числі й у повісті Кузьми Скрябіна «місто $\epsilon$ всього лищ ареною дій та подій, не має яскраво виражених ознак дружньості/ворожості й зображене абстрактно» [8]. Здається, 3 цією думкою не можна погодитися 3 огляду на виразну увагу до особливості 
просторових координат, специфічну вилученість зображеного міста 3 нормативного простору. Таке попереднє припущення веде необхідності визначити методологію дослідження в контексті геопоетики та, конкретніше гетеротопічності.

Геопоетичний дискурс у сучасному літературознавстві $є$ одним iз важливих підходів до принципово нового розуміння взаємозв'язків між дійсністю та фікцією. Актуальні філософські підходи, деконструюючи 3 позицій нейрофізіології та особливостей людського «я» саме поняття реальності, ставлять під сумнів продуктивність дальшого послугування простим протиставленням світу емпіричного та світу художнього (огляд концепції феноменальної Я-моделі $\mathrm{T}$. Метцингера та методологічні iï перспективи для аналізу простору я здійснив в окремій розвідці [9] ). Відтак набуває нового значення осмислення, зокрема, художніх просторових моделей.

Художній простір як складова художнього світу традиційно розглядався у протиставленні до простору світу реального як спадок міметичної аристотелівської концепції творчості. Засади ж геопоетики грунтуються на переосмисленні дискурсу внутрішніх закономірностей світу художнього. Уже в феноменологічних студіях (М. Мерло-Понті, Г. Башляр) сформовано уявлення про культурну значущість простору - насамперед, як простору життя (франц. espace vécu); певним віддзеркаленням є семіотичний підхід Ю. Лотмана, який зосередився на культурологічній значущості просторових відношень. У наратологічних пошуках було визначено «зачарованість простором» літератури модернізму (Ж. Женетт), склалася концепція дейктичного зсуву (англ. deictic shift), яка передбачає, що читач у процесі рецепції переміщується в особливий наративний світ [10], та було розроблено й деталізовану інтерпретаційну сітку власне наративного простору [11].

Конвенція геопоетики, як і просторового повороту, тісно пов'язана 3 ім'ям автора поняття - К. Вайтом, - однак іï першооснови в гуманітарних науках закладені завдяки впливу ідей А. Лефевра та М. Фуко; на значенні обох 
ISSN 2308-1902 Актуальні проблеми української літератури і фольклору. 2017. № 25.

мислителів наголошували, приміром, Е. Сойя $[12,18]$ та Е. Рибицька $[13,20]$. Підкреслюючи поновочасну захопленість людини простором, М. Фуко акцентує, що просторові концепції завжди були важливими, однак «у нашу еру простір презентує себе у формі паттернів впорядкування» (англ. «In our era, space presents itself to us in the form of patterns of ordering») [14, 331]. Окрім того, спираючись на ідеї Г. Башляра, М. Фуко стверджує неминучу конотованість та динамізм просторових параметрів, у зв'язку 3 чим виникає концепція особливим чином організованих просторів - гетеротопій. «Також існують, $і$ ие напевно правдиво для всіх культур та циивілізацій, реальні та дієві простори, які відмежовані самою організацією суспільства, але які складають певну протиставленість до ефективно реалізованої утопії; у яких всі дійсні відносини, геть усі реальні відносини, щэо їх можна знайти в суспільстві, одночасно наявні, оскаржуються та скасовуються: ие таке місие, яке лежить поза всіма місиями, але все ще може бути локалізоване. За контрастом до утопій, ці місия, абсолютно відмінні за представлюваними та промовлюваними ними відношеннями, можуть бути описані як гетеротопіï» (англ. «There also exist, and this is probably true for all cultures and all civilizations, real and effective spaces which are outlined in the very institution of society, but which constitute a sort of counter arrangement, of effectively realized utopia, in which all the real arrangements, all the other real arrangements that can be found within society, are at one and the same time represented, challenged, and overturned: a sort of place that lies outside all places and yet is actually localizable. In contrast to the utopias, these places which are absolutely other with respect to all the arrangements that they reflect and of which they speak might be described as heterotopias») [14, 332]. Аналізуючи це визначення, можна сформулювати основні особливості гетеротопії: по-перше, це особливий статус у структурі суспільства («outlined in the very institution of society»); по-друге, ефективна внутрішня боротьба 3 суспільними відносинами («real arrangements ... are at one and the same time represented, challenged, and overturned»); по-третє, можливість чіткої локалізації 
(«actually localizable»). Також прикметно, що автор надає гетеротопії універсального, метакультурного статусу («this is probably true for all cultures and all civilizations»). М. Фуко виділяє два історичні типи гетеротопій: кризи (пов'язана з віковими та статусними обмеженнями у примітивному суспільстві) та девіації (пов'язана з порушеннями суспільної норми). Важливо, що філософ утверджує ідею історичної зміни функції гетеротопій (зокрема, на прикладі цвинтарного простору) $[14,332]$ та констатує, що гетеротопія завжди поєднує внутрішньо несумісні параметри [14, 333].

Вокабуляр вимишлених просторів не є відкриттям XX-XXI століть. Навіть якщо не брати до уваги родові поняття, то від щонайменше XVI століття в обіг риторики (завдяки Еразму Роттердамському, Йоганнесу Зузенброту, Генрі Пішему) увійшло поняття «топотезія», що тлумачиться як «опис місия, якого нема в реальності» $[15,13]$. У. Еко, обмірковуючи особливості структури простору вимишлених світів, пропонує виділити алотопії, утопії, ухронії та метатопії [16, 235-236]. Під час аналізу повісті К. Скрябіна варто говорити більшою мірою про вимишлене місце, топос, а не вимишлений світ у цілому, хоча масштаби розбіжностей з реальністю виходять поза межі власне зони відчуження: вже по здобутті Україною незалежності на станції трапився новий вибух; інша логіка залізничної логістики; тотальна контрольованість периметру та включеність експерименту в потаємні структури міжнародної фармацевтики.

Аналіз просторових параметрів вимагає спеціального обумовлення референтного статусу художньої топографії. Із одного боку, референція, здається, не-нульова: прямо називається місто - Прип'ять; вокзал, на який прибуває Аліса - це, імовірно, залізнична станція Янів; «цвинтар похованої після аварії на атомній станщії техніки» [7, 126] - Розсохинський відстійник техніки. Із іншого боку, чимало умовностей змушують говорити про певне згущення простору, створення компактного образу Зони. Географічно Прип'ять та залізнична станція Янів в емпіричній реальності справді перебувають між Києвом та Білоруссю, але поїзд із Києва має небагато шансів їхати через Янів - 
ISSN 2308-1902 Актуальні проблеми української літератури і фольклору. 2017. № 25.

у силу розташування транспортних гілок. Між Прип’яттю та Розсохою 3 iї технічним цвинтарем кількадесят кілометрів дорогою, що не узгоджується 3 описом: «Вони їхали з двадиять хвилин» [7, 141]. Окрім того, у сюжеті фігурують лабораторії та санаторії. Відтак, можна 3 певністю констатувати неміметичність простору, його алотопічність (у значенні, яке вкладає в це поняття К. Май [17]), де Чорнобиль постає символічною локацією пострадянської дійсності.

Сюжетно-композиційно повість обрамлена мотивом дороги, подорожі: київський вокзал присутній і на початку твору (дія починається навесні), i наприкінці («вокзал буяв осінніми настроями» [7, 157]). Життя Аліси перед подорожжю закінчується символічно, із точки зору самої дівчини (нема роботи та коханця), по поверненні - завершується насправді («завтра сонще встане $i$ зігріє той світ, на якому їх обох вже не буде» [7, 158] ). Таким чином, шлях у повісті є дієвим символом переходу, межової ситуації.

Дорога до гетеротопічного міста Прип'яті (і з нього) відкривається тільки двічі на рік: «коли переводять стрілки годинника» [7, 101]. Це має сенс у прагматичному розумінні (легше приховати різницю в маршрутах), і водночас, у символічному: переведення стрілок $є$, на мою думку, свого роду модерною формою рівнодення - сакрального часу древніх епох.

Аліса потрапляє в Місто на поїзді. Сама ситуація подорожі оповита містичними мотивами, які надалі в повісті не прояснюються: прокинувшись у своїй київській квартирі, дівчина знаходить конверт із залізничним квитком. Подорож $є$ невмотивованим актом відчаю, зумовленим невлаштованістю героїні (розлучення з хлопцем, втрата роботи). Це буквально мандрівка в нікуди: «У графі «місие призначення» було написано місто, яке Аліса ніяк не могла згадати на швидку руку» [7, 84], - саме цей мотив надалі відіграє вирішальну роль у іiі долі. Збіги на початку шляху накопичуються: згаданого міста немає в атласі, таксист, який везе дівчину до вокзалу, забуває, попри властиву його профілю звичку, спитати, куди їде його пасажирка, а в касі при 
згадці про пункт призначення кажуть, «щ̧о найближчий дурдом через дві вулиціџ» $[7,85]$.

Чорнобильський простір накреслюється пересуваннями героїні, тому очевидно, що відкривається Місто вокзалом. Слід відзначити, що гетеротопічність вокзалу як окремого локусу розглядається в сучасних літературознавчих [18] та соціальних студіях, де тлумачиться як «гетеротопія потоків» [19]. Аліса прибуває у пункт призначення вночі, потрапляючи на типову стару залізничну станцію: старий неосвітлений перон, запах дизельного погару, важкі двері [7, 90]. Цікавим елементом реалізації простору на цьому сюжетному етапі $є$ хіба що свого роду «доповнена реальність»: «Калюжі стояли тут навіть тоді, коли декілька днів світило сонцее» [Там само]. Фокалізація наративу, до того зосереджена на досвіді Аліси, розширюється до ширшого спостерігача, психологічно більш вільного, аніж шокована героїня.

Мандрівка героїні Містом спершу дзеркально відображає іiі від’їз 3 Києва: в обох містах вона їхала таксі, але в чорнобильській локації це пересування супроводжується як розкриттям сюжетної інформації (розвиток мотиву розплати послугами, уявлення про своєрідний «кодекс честі», що забороняє надміру принижувати новачків), так і зрештою, остаточним зламом дзеркала: по інший кінець мандрівки Аліса опиняється в готелі - ще одному транзитному просторі, певною мірою протилежному «своєму» локусу квартири.

Отілеснення міського простору реалізується у творі радикально - у відповідності до вихідного припущення автора: героїню змушують у якості штрафу пробігти п’ятдесят кіл довкола вокзалу, потім - прострибати від таксі до готелю через калюжу; транзитний простір готелю Аліса освоює вже й геть натуралістично: миє власним волоссям туалети. Таким чином, можна констатувати насильницьке, фізіологічне включення героїні в структуру топосу Міста. Ця ж логіка продовжується сюжетною лінією генетичних експериментів, яку я розгляну окремо в контексті антиутопізму повісті. 
ISSN 2308-1902 Актуальні проблеми української літератури і фольклору. 2017. № 25.

Пополудні міське середовище не видається героїні чимось дивним: «По вулиці ходили з вигляду абсолютно нормальні люди, в абсолютно нормальних, земних справах. Такі ж нормальні будинки замикали над собою небо в квадрати, як $і$ будинки в ї̈ рідному місті, не давали забути, що небо тримається тільки і виключно на їхніх бетонних стінах. Варто тільки підняти голову догори і хмари, які пливуть над тобою, створюють ілюзію, що будинок падає просто на тебе, і ти відскакуєш. Так пару разів поспіль, аж поки не звикнеш до обману» [7, 105]. Знову впадає в око доповнена реальність виповідання простору, тобто, при розгляді твору крізь наратологічну оптику помітний перехід до «нульової фокалізації» (Ж. Женетт). Принагідно слід зауважити, що процитована просторова рамка є єдиною урбаністичною, містить упізнавані міські маркери (прямі кути неба, багатоповерхівки). Не останню роль в акліматизації Аліси до Міста відіграє саме звичність - як у цьому епізоді, де знайомою є певна глобальна метафора простору (небо тримається на будинках), так і в наступній просторовій рамці в «Бістро». Заклад просторово деталізований мінімально («старий зачуханий будинок із надписом “Бістро”» $[7,106]$, однак його зв'язок із фізіологічними потребами швидко повертає Алісі частину впевненості, тож у діалозі з продавчинею дівчина вже почувається цілком вільно - торгується, свариться. Дальше «нахабнішання» героїні збігається з упізнанням пісні, почутої з вікна $[7,110]$.

Серйозно пошкоджене дорожнє покриття $є$ загалом прикметним i повторюваним маркером Міста. Починаючи від першого зорового враження на пероні вокзалу, зруйнований асфальт стає неодмінним атрибутом міського простору: навпроти готелю [7, 98], на вулиці за «Бістро» [7, 109-110], дорогою до схованки Фріца [7, 120]. Показовою $є$ характеристика цих ям як самодостатньої реальності: «Величезні ями переорювали асфальт $і$ були єдиними свідками всього, щэо відбувалося у ціий нудній місцині. Вони одні знали все про цей район. I нікому не збиралися відкривати иуих таємнищь. Аліса обходила ямеги боком, ніби боялася, вступивщи в одну з них, упасти аж на дно 
самої Землі. Не маючи поняття насправді, де воно знаходиться, це дно. Чи в центрі, чи, може, десь під протилежним боком землі - під Аргентиною або Чилі» [7, 109-110]. Іронічна гіпербола, абсурдизація, яку можна помітити в цитаті, $є$ не менш типовим прийомом обниження просторового переживання в повісті. Так само, наприклад, реалізується візит на цвинтар (відстійник) зараженої техніки. Аналогічно до вже зауважених випадків констатую нульову фокалізацію: «Вони їхали на цвинтар похованої після аварії на атомній станиії техніки. Рівень радіації був там такий високий, щэо, навіть проїжджаючи за кілометр від нього, ти прекрасно відчував, як твої яйця стають зовсім прозорими. Навколо ичвинтаря була виставлена сяка-така охорона з трьох чоловік, які постійно грали в карти...» $[7,126]$. Цей цвинтар зображується як «місто мертвих машин» $[7,127]$ або «техномогили» $[7,126]$, що відгороджені від навколишнього світу тільки заіржавілим колючим дротом [7, 141] та шлагбаумом $[7,126,136]$. Цвинтар має уявний центр, наскрізно позначений образами іржі та радіації (фон, радіоактивний пил).

Топос цвинтаря є сам по собі гетеротопічним - саме так розглядав його М. Фуко: як «інше місто» [14, 334]. Зображена в аналізованій повісті гетеротопія відповідає другому етапові розвитку традиційного «іншого місця»: філософ констатував, що цвинтар був зсунутий на периферію міста 3 XIX століття, відчужений внаслідок побоювань чуми та інших інфекцій [Там само]. Відстійник техніки є крайнім, хворобливо деформованим варіантом пізньої версії цвинтаря: до нього приїжджають не родичі померлих, а символічні плюндрувальники могил - люди, яким треба «відкрутити деталі»; загрозливий бестіарій не вимишлений культурною традицією, але цілком реальний (згадано кабанів-мутантів [7, 126]). Нарешті, цвинтар справді заражений, але не середньовічною чумою, а цілком сучасною радіацією.

Локус закинутого дому, який став місцем переродження героїні (див. вище), також маркований як гетеротопія: це інше місце, не належне епосі. Він $\epsilon$, властиво, таким самим цвинтарем, могилою - для попередньої культурної 
ISSN 2308-1902 Актуальні проблеми української літератури і фольклору. 2017. № 25.

епохи (рустикальний спосіб життя), політичної епохи (радянський лад), для речей. Подібно до кладовищного простору він має зображення померлих, а крісла колишніх мешканців, які рахує героїня, вражаюче нагадують могили.

Відтак слід констатувати, що перехід героїні через цвинтарний локус закинутого будинку позначає перехід до самодеструктивної фази. Аліса стає вбивцею, виходить поза межі правил і свого «рідного» світу, і реальності Міста.

Розглядаючи повість Кузьми Скрябіна як антиутопію, окремо хочу звернути увагу на те, як організована в ній влада. Функція контролю у творі фактично виявляється позапросторово, але, тим не менш, - у відповідності до принципів тюремної гетеротопії. Зокрема, «Місто, в якому не ходять гроші» відповідає фукіанському принципу паноптизму - феномену, який М. Фуко у праці «Наглядати й карати» вводить як похідний від запропонованого Дж. Бентамом проекту тюрми. «Основна мета паноптикона: привести ув'язненого у стан усвідомлюваної й постійної видимості, яка забезпечує автоматичне функиіонування влади» (рос. «основная ичель паноптикона: привести заключенного в состояние сознаваемой и постоянной видимости, которая обеспечивает автоматическое функичонирование власти») [20, 294]. М. Фуко знаходить коріння паноптизму в порядку боротьби з чумою. Філософ заперечує карнавальний характер епідемії, показуючи, що на пошесть політичний устрій відповідає сегментуванням простору та тотальним контролем: «...місто, знерухомлене розширеною владою, яка в тій чи іншій формі впливає на всі індивідуальні тіла - ось утопія досконало керованого міста» (рос. "...город, обездвиженный расширивиейся властью, которая в той или иной форме воздействует на все индивидуальные тела, - вот утопия совершенно управляемого города») [20, 291].

Коли Аліса потрапляє в Місто, перша аномалія, яку вона бачить - зміна кольору шкіри в касира на вокзалі. Пізніше в готелі портьє пояснює їй причину: це спеціальні медикаменти, що перетворюють місто на свого роду «паноптикон»: «Колір шкіри, який змінюється залежно від емоційного стану, - 
прояв після їх приймання. ... Вони є в їжі, у воді, скрізь. Це було запроваджено для того, щоб людину було видно, як на долоні. Щоб не можна було приховати щось. Тут майже відсутня злочинність. Коли в кров виділяється особливий гормон, який нерозривно пов'язаний із бажанням скоїти злочин, - вона починає видавати в повітря специфічний запах, і його тут же ізолюють, якщо він на виду. Поліція тут всюди. Роботи в них майже нема» [7, 101]. Трансгуманістичні експерименти насправді не $\epsilon$ за своїм принципом новаторськими, оскільки є прямим продовженням роботи влади 3 людським тілом. Реалізація розподільних функцій влади здійснюється в Місті в форматі своєрідної розімкненої просторово тюрми з однобічною прозорістю. Вигадана Кузьмою Скрябіним реальність тільки поглиблює наглядову функцію влади за рахунок іï поширення напряму на фізіологію. Але, зрештою, як твердить М. де Серто, політична структура завжди прагнула опанувати шкіру учасника соціуму: «Ціла традиція повідує історію: шкіра слуги є пергаментом, на якому пише рука власника ... Від засобів шрамування, татуювання і примітивної ініціачії до інструментів карального правосуддя, інструменти прачюють 3 тілом» (англ. "A whole tradition tells the story: the skin of the servant is the parchment on which the master's hand writes ...From the instruments of scarification, tatooing, and primitive initiation to those of penal justice, tools work on the body») [21, 140-141].

Не менш показово, що Кузьма Скрябін послідовно пов'язує виникнення своєї антиутопії з триванням радянської традиції. «Заправляють у намому місті-концтаборі троє потомків людей, які ие все вигадали. Їхні предки служили в органах за Совєцького Союзу» [7, 101]; «Коли партія віддала наказ їхати в Зону, Олег Сергійович втратив жінку» [7, 142] ; «То була стара армія спецслужб. Стара совкова закалка. Такі люди при будь-якій владі на вагу золота» $[7,147]$. Новий катаклізм у Зоні за десять років до подій повісті цілком у дусі радянського часу втаємничується владою України; приймається рішення про перетворення наново закритої Зони на випробувальний медичний полігон. 
ISSN 2308-1902 Актуальні проблеми української літератури і фольклору. 2017. № 25.

У зв'язку 3 цим дбайливо збережено принцип виділення спеціальних співробітників ув окрему касту: «Люди, які пращювали в лабораторіях, ніколи не контактували з жителями міста» [7, 147]. У зв'язку з розвитком біохімії, генної інженерії, винайденням «машини старіння» можна говорити про часткове накладання на світ повісті так званого «критерія Дозуа»: «Високі технології - низький рівень життя» (англ. «High tech, low life»), - який використовується на позначення кіберпанку, але його реалізація досить часткова: досягнення прогресу практично недоступні рядовим мешканцям Зони, ними користуються тільки експериментатори та багаті туристи 3-поза меж Міста. На решту поширюються тільки каральні функції цих винаходів: гормональні маркери та відбирання молодості.

Тоталітарний дискурс у такий спосіб сполучається 3 неототалітарним, відбувається консервування та посилення (буквально - розкриття метафори «тілесності») атрибутів наглядового апарату, однак не менш помітною $є$ й збереженість традицій недбалості та «кризи виконавців»: помилковий квиток у Місто для Аліси, неувага «поліціянтів» до агресивного Фріца (попри декларативний «паноптикон»), дії тієї ж поліції після розстрілу, влаштованого Алісою. Окремої уваги в цьому контексті заслуговує ситуація на КПП звалища зараженої техніки: «Навколо извинтаря була виставлена сяка-така охорона 3 трьох чоловік, які постійно грали в карти... Машина з паџанами під'їхала до шлагбаума, Фріи пригальмував, вийшов $i$ поскакав до вагончика. Там він переговорив з одним охоронцем, дав йому пару сигарет $i$ банку тої синьої кислоти, а точніше, те, щңо в ній лишилося від його інвазії, чим викликав дикий ажіотаж серед вічних охоронщів техномогил» $[7,126]$. Автор актуалізує те, що залишалося поза офіційним тоталітарним дискурсом, показує живучість управлінських та організаційних практик. На мою думку, відтак, антиутопія в іiі пострадянській іпостасі ефективно деконструюється автором. Декларована цілісність державного тіла не реалізована повною мірою, або, послуговуючись метафорикою М. де Серто, «Логос суспільства» так і не стає «плоттю». 
Неофіційним радянським дискурсом деконструюється й ключова засада «паноптизму»: забезпечення однобічної прозорості влади. 3 одного боку, всі мешканці Зони розуміють і приймають механізм контролю, однак, усі знають, що керують усім колишні партійні еліти (ті самі «троє потомків»), але при цьому Лєший хизується своїм статусом сина головного управлінця («Miŭ старий праџюе в мерї, так щуо не шукай собі на голову менінгіт» $[7,111])$, i його оточення про це знає («Старий Лєшого мерію підніме, нас закопають Hapir» [7, 120] ).

Підсумовуючи аналіз структури міської гетеротопії Прип'яті, слід відзначити, що вона має характер «фракталу», тобто, складається практично винятково з гетеротопій нижчого порядку: вокзал, готель, бістро, цвинтар, лікарня-лабораторія, і замикається знову вокзалом. Система цих гетеротопій маркує фази перетворень Аліси, кожна з них зокрема позначає окремий етап змін у свідомості героїні. Гетеротопічність Прип'яті як просторового цілого зумовлена сполученням внутрішньо невідповідних ознак: це водночас тюрма i гра (мотив кінофільму, ігрове відкриття міста двічі на рік), простір катастрофи і простір відкриттів, місто високотехнологічне та занедбане, вкорінене в минуле та деформує майбутнє, позірно контрольоване та безпорадне перед несподіванками.

Простір Міста дискретний, умовно референтний, однак його топографія збігається більшою мірою з уявним Чорнобилем. Символічно, що в повісті відсутня просторово, жодного разу не згадується впізнавана структура атомної станції. Прип'ять є простором духовного розпаду, руйнування та смерті. Складники-гетеротопії ієрархічно складаються у структуру 3 виразним домінуванням цвинтаря - принаймні, тільки цвинтар двічі фігурує в повісті (окремо стоїть гетеротопія вокзалу, яка навантажена більшою мірою на сюжетно-композиційному та архетипному рівнях прочитання). Зміни фокалізації, згрубілість та іронія ховають виповідання найчорніше маркованих місць / елементів простору. 
ISSN 2308-1902 Актуальні проблеми української літератури і фольклору. 2017. № 25.

Антиутопізм повісті Кузьми Скрябіна є позірним, це дієва деконструкція радянської версії організації соціуму. Антиетичний експеримент, спроба отілеснення влади, чергова версія скасування грошей, досліди - і при цьому управлінська криза, руйнування паноптизму, найгірші радянські традиції недбалості.

Кузьма Скрябін, на моє переконання, завершив оформлення образу чорнобильської зони, витворивши модель радикального відчуження й водночас упізнаваності умовного простору Чорнобиля: простору страхів не тільки перед минулою катастрофою, але й перед тяглістю бездуховного минулого.

\section{ЛІТЕРАТУРА}

1. Гундорова T. Післячорнобильська бібліотека. Український літературний постмодерн. Київ : Критика, 2005. 264 с.

2. Семенов C. Дискотека с манекенами. Expert.ua. URL: http://expert.ua/articles/14/0/1817/ (дата звернення: 18.11.2017).

3. Бондар-Терещенко I. "Побєда" Скрябіна i вапше. Vsiknygy.net. URL: https://vsiknygy.net.ua/shcho_pochytaty/review/947/ (дата звернення: 18.11.2017).

4. “Я, «Побєда» і Берлін” Кузьми Скрябіна. Livejournal.com. URL: http://leorina.livejournal.com/78457.html (дата звернення: 24.11.2017).

5. Саган Г. В. Особливості індивідуального стилю прозописьма Андрія Кузьменка (Кузьми Скрябіна). Вісник Луганського національного університету імені Тараса Шевченка. Філологічні науки. 2011. № 17 (228). С. 101-106.

6. Лауда Л. Кузьма видав аудіокнигу “Я, «Побєда» і Берлін”. Gazeta.ua. URL: http://gazeta.ua/index.php?id=220817 (дата звернення: 23.11.2017).

7. Кузьма Скрябін. Місто, в якому не ходять гроші. Я, “Побєда” і Берлін. Харків : Фоліо, 2006. С. 81-159.

8. Стусенко О. Апологія відсутності (про місто/село як бінарну опозицію). Litakcent.com. URL: http://litakcent.com/2008/04/14/oleksandr-stusenko-apolohija-vidsutnosti-promistoselo-jak-binarnu-opozyciju/ (дата звернення: 17.11.2017).

9. Цікавий C. Особливості художнього простору в літературі: деякі філософські та нейрофізіологічні аспекти. Наукові праці Кам'янець-Подільського національного університету імені Івана Огієнка: Філологічні науки. Випуск 45. Кам'янець-Подільський : Аксіома, 2017. C. 227-230.

10. Galbraith M. Deictic Shift Theory and the Poetics of Involvement in Narrative. Deixis in Narrative: A Cognitive Science Perspective / Ed. by Judith F. Duchan, Gail A. Bruder and Lynne E. Hewitt. Hillsdale, NJ : Lawrence Erlbaum, 1995. P. 19-59.

11. Ryan M.-L. Space. The living handbook of narratology / Hühn, Peter et al. (eds.) URL: http://www.lhn.unihamburg.de/article/space. (last accessed: 17.11.2017).

12. Soja E. Taking space personally. The spatial turn. Interdisciplinary perspectives / Ed. by Barney Warf and Santa Arias. London, New-York : Routledge, 2009. P. 11-35.

13. Rybicka E. Geopoetyka. Przestrzeń i mejsce we współczesnych teoriach i praktykach literackich. Kraków : UNIVERSYTAS, 2014. 474 s.

14. Foucault M. Of Other Spaces: Utopias and Heterotopias. Rethinking Architecture: A Reader in Cultural Theory / Ed. by Neil Leach. New York : Routledge. 1997. P. 330-336. 
15. Michałowska T. Kochanowskiego poetyka przestrzeni : wizja horyzontalna. Pamiętnik Literacki : czasopismo kwartalne poświęcone historii i krytyce literatury polskiej. 1979. № 70/1. S. 3-30.

16. Eco $U$. Światy science fiction. Po drugiej stronie lustra $i$ inne eseje : znak, reprezentacja, iluzja, obraz / Przeł. Joanna Wajs. Warszawa : Wydawnictwo W.A.B., 2012. S. 233241. $315 \mathrm{~s}$.

17. Maj K. Allotopie. Topografia swiatów fikcjonalnych. Kraków : UNIVERSITAS, 2015.

18. Knight K. Real Places and Impossible Spaces: Foucault's Heterotopia in the Fiction of James Joyce, Vladimir Nabokov, and W.G. Sebald : Thesis submitted for the qualification of Doctor of Philosophy. Norwich : University of East Anglia, 2014. 216 p.

19. Stikells L. Flow urbanism. The heterotopia of flows. Heterotopia and the City: Public space in postcivil society / Ed. by Michiel Dehaene and Lieven De Cauter. London; New York : Routledge, 2008. P. 247-257.

20. Фуко М. Надзирать и наказывать / Перевод: В. Наумов. Москва : Ad Marginem, 1999. $480 \mathrm{c}$.

21. Certeau de M. The Practice of Everyday Life. Berkeley : University of California Press, 1984. 229 p.

\section{References}

1. Hundorova, T. (2005). Pisliachornobylska biblioteka. Ukrainskyi literaturnyi postmodern [Post-Chornobyl Library. Ukrainian Literary Postmodern]. Kyiv: Krytyka. [In Ukrainian].

2. Semenov, S. (2006, March 25). Dyskoteka z manekenamy [Disco-party with mannequins]. Retrieved from http://expert.ua/articles/14/0/1817/ . [In Ukrainian].

3. Bondar-Tereshchenko, I (2009, May 18). "Pobieda" Skriabina i vapshe [Skriabin's "Victory" and so on]. Retrieved from https://vsiknygy.net.ua/shcho_pochytaty/review/947/. [In Ukrainian].

4. N. a. (2007, September 12) "Ia, «Pobieda» i Berlin” Kuzmy Skriabina [“Me, 'Victory' and Berlin" by Kuzma Skriabin]. Retrieved from http://leo-rina.livejournal.com/78457.html. [In Ukrainian].

5. Sahan, H. (2011). Osoblyvosti indyvidualnoho styliu prozopysma Andriia Kuzmenka (Kuzmy Skriabina) [Peculiarities of Andrii Kuzmenko's (Kuzma Skriabin) Individual Style of Poetic Writing]. Visnyk Luhanskoho natsionalnoho universytetu imeni Tarasa Shevchenka. Filolohichni nauky, (17 (228)), 101-106. [In Ukrainian].

6. Lauda, L. (2008, April 10). Kuzma vydav audioknyhu "Ia, «Pobieda» i Berlin” [Kuzma Published Audiobook “Me, 'Victory' and Berlin]. Retrieved from https://gazeta.ua/articles/culturenewspaper/_kuzma-vidav-audioknigu-a-pobyeda-i-berlin/220817. [In Ukrainian].

7. Kuzma Skriabin (2006). Misto, v yakomu ne khodiat hroshi [The City Without Money] In Kuzma Skriabin “Ia, «Pobieda» $i$ Berlin”. Kharkiv: Folio, 81-159 [In Ukrainian].

8. Stusenko, O. (2008, April 14). Apolohiia vidsutnosti (pro misto/selo yak binarnu opozytsiiu) [Apology of Absence (On City/Village as Binary Opposition)]. Retrieved from http://litakcent.com/2008/04/14/oleksandr-stusenko-apolohija-vidsutnosti-pro-mistoselo-jakbinarnu-opozyciju/. [In Ukrainian].

9. Tsikavyi, S. (2017). Osoblyvosti khudozhnoho prostoru v literaturi: deiaki filosofski ta neirofiziolohichni aspekty [Features of the Artistic Space in the Literature: Some Philosophical and Neurophysiological Aspects]. Naukovi pratsi Kam'ianets-Podilskoho natsionalnoho universytetu imeni Ivana Ohiienka: Filolohichni nauky. Vypusk 45, Kam'ianets-Podilskyi: Aksioma, 227-230. [In Ukrainian]. 
ISSN 2308-1902 Актуальні проблеми української літератури і фольклору. 2017. № 25.

10. Galbraith, M. (1995). Deictic Shift Theory and the Poetics of Involvement in Narrative. In Judith F. Duchan, Gail A. Bruder and Lynne E. Hewitt. Hillsdale (Eds.) Deixis in Narrative: A Cognitive Science Perspective, New Jersey: Lawrence Erlbaum, 19-59.

11. Ryan, M.-L. (2014, April 22). Space. Retrieved from http://www.lhn.unihamburg.de/article/space .

12. Soja, E. (2009). Taking space personally. In B. Warf and S. Arias (Eds.), The spatial turn. Interdisciplinary perspectives, London, New-York: Routledge, 11-35.

13. Rybicka, E (2014). Geopoetyka. Przestrzeń $i$ mejsce we wspótczesnych teoriach $i$ praktykach literackich. [Geopoetics. Space and place in contemporary theories and literary practices] Kraków: UNIVERSITAS. [In Polish].

14. Foucault, M. (1997). Of Other Spaces: Utopias and Heterotopias In N. Leach (Ed.), Rethinking Architecture: A Reader in Cultural Theory, New York: Routledge, 330-336.

15. Michałowska, T. (1979). Kochanowskiego poetyka przestrzeni: wizja horyzontalna [Kochanowski's poetics of space: horyzontal vision]. Pamiętnik Literacki : czasopismo kwartalne poświęcone historii i krytyce literatury polskiej, (70/1), 3-30. [In Polish].

16. Eco, U. (2012). Światy science fiction [Science fiction spaces]. In Umberto Eco Po drugiej stronie lustra i inne eseje : znak, reprezentacja, iluzja, obraz. (J. Wais, Trans.). (pp. 233241).Warszawa: Wydawnictwo W.A.B. [In Polish].

17. Maj, K. (2015). Allotopie. Topografia swiatów fikcjonalnych [Allopiae. Topographia of fictional spaces]. Kraków: UNIVERSITAS. [In Polish].

18. Knight, K. (2014). Real Places and Impossible Spaces: Foucault's Heterotopia in the Fiction of James Joyce, Vladimir Nabokov, and W.G. Sebald: Thesis submitted for the qualification of Doctor of Philosophy. Norwich: University of East Anglia.

19. Stikells, L. (2008). Flow urbanism. The heterotopia of flows. In Michiel Dehaene and Lieven De Caut (Eds.), Heterotopia and the City: Public space in postcivil society. (pp. 247-257). London; New York: Routledge, 2008.

20. Foucault, M. (1999). Nadzirat i nakazyvat (V. Naumov, Trans.) [Discipline and Punish]. Moscow: Ad Marginem, [In Russian]. (Original work published in 1975).

21. Certeau de, M. (1984). The Practice of Everyday Life. Berkeley: University of California Press.

\title{
Аннотация
}

Сергей Цикавый. Антиутопия и гетеротопия: фикциональный город-тюрьма в повести Кузьмы Скрябина «Город, в котором не ходят деньги»

Статья посвящена анализу художественного пространства Чернобыльской зоны в малоисследованной повести А. Кузьменко. Коротко очерчены основные концепции пространственности в контексте геопоэтического дискурса современной гуманитаристики. Наблюдаются признаки разрушения референтной связи пространства Зоны с реальным. Определено, что сконструированное нарративное пространство может быть очерчено как гетеротопическое. Постсоветская антиутопическая составляющая произведения в повести эффективно деконструирована.

Ключові слова: місто, простір, локус, топос, паноптикон, антиутопія.

\begin{abstract}
Serhii Tsikavyi. Anti-utopia and heterotopia: fictional carceral city in story "The City Without Money" by Kuzma Skriabin

The article represents an attempt of geopoetical view on post-Chornobyl story by famous Ukrainian poet and pop-singer A. Kuzmenko (a.k.a. Kuzma Skriabin). Analyzed text is the part of Ukrainian postcolonial and at the same time postmodern discourse, coined by T. Hundorova as "postChornobyl Library". In the article based on ideas of U. Eco, M. Foucault and M. de Certeau an analysis of spatial frames and special narrative is being conducted. It is supposed that the topical
\end{abstract}


parameters of the story could be interpreted in terms of "heterotopia" ("other space" which mixes cultural semantics, effectively excluded from the order of human space) and "anti-utopia". The City, linked for sure with its prototype, Prypiat, is composed of heterotopias of lower level: railway station, cemetery, hotel, hospital and so on. The most powerful and valuable for plot spatial frames in the story are those with semantics of graveyard: depot of contaminated machines and empty rural house, which preserved signs of pre-evacuation life. It was proven that the transformation of Alisa, the heroine of the story, is marked with those catastrophic loci.

The embodiment of power in the City was also traced. Transhumanistic experiments conducted in the City are interpreted as totalitarian practice: both idea of "panopticon" (M. Foucault) and inscribing of power in skin (M. de Certeau). The post-Soviet nature of totalitarianism is at the same time an effective deconstruction of the idea of total control: unilateral transparency, effectiveness of repression machine are doubted in organization of the City. The key communist utopical idea (exclusion of money) symbolically marks the failure of total idea.

Key words: city, space, locus, topos, panopticon, anti-utopia.

Стаття надійшла до редакційної колегії 04.12.2017 року 